\title{
EVALUATION OF ANTI-ALZHEIMER ACTIVITY OF ETHANOLIC AND METHANOLIC EXTRACTS OF POLYGONUM GLABRUM AGAINST ALUMINUM CHLORIDE-INDUCED ALZHEIMER'S IN EXPERIMENTAL RATS
}

\author{
SUNEESHA Y, VINAY KUMAR T* \\ Department of Pharmacology, Nirmala College of Pharmacy, Atmakur, Andhra Pradesh, India. Email: vinaykumartheendra@gmail.com \\ Received: 06 October 2020, Revised and Accepted: 12 November 2020
}

ABSTRACT

Objective: The current study aimed at the investigation of the effectiveness of ethanolic and methanolic extract of Polygonum glabrum in aluminum chloride-induced Alzheimer's disease in experimental rats.

Methods: The behavioral parameters evaluated by following methods such as Morris water maze test, radial arm maze test, and active avoidance test. Biochemical parameters were also estimated such as acetylcholine and acetylcholine esterase.

Results: Polygonum glabrum extract was instituted to be neuroprotective against $\mathrm{AlCl}_{3}$-induced toxicity. Enhanced learning and memory were allied to the ingestion of extract in rats. Al overload, acetylcholinesterase enzyme hyperactivity is responsible for Alzheimer's disease which is neutralized or reduced with treatment of extract, which might be due to the synergistic action of its active constituents. Ethanolic extract was shown slightly higher efficacy as compared to methanolic extract.

Conclusion: Based on these current findings, it is suggested that lowering $A \beta$ is an unproven strategy, and it may be time to refocus on other targets for the treatment of this disease, including pathological forms of tau.

Keywords: Alzheimer's disease, beta-amyloid plaque, $\mathrm{A} \beta$ peptide.

(c) 2021 The Authors. Published by Innovare Academic Sciences Pvt Ltd. This is an open access article under the CC BY license (http://creativecommons.org/ licenses/by/4.0/) DOI: http://dx.doi.org/10.22159/ajpcr.2021v14i1.39934. Journal homepage: https://innovareacademics.in/journals/index.php/ajpcr

\section{INTRODUCTION}

Alzheimer's disease is considered to be in responsible of around $60 \%$ of all mental disorder in older adults or moderately aged [1] and influence in more than of 5 million Americans, a number assessed to augmentation to 7.7 million by means of 2030 .

Alzheimer's disease is caused because of aggregation of misfolded proteins buildup of deposits of fibrillary amyloid in selective areas of the central nervous system. Alzheimer's disease leads in memory loss, unusual behavior, personality changes, and loss of the capability to thinking. Early disease exhibits short-term memory loss, fail to retain information names and addresses, not able to learn novel information, mood swings, as the circumstance develops, transform becomes more prominent, and persons even forget way to home. Frustration, hostility, and irritability are typical emotional features exhibited by means of AD patients. Genetic factors are responsible for $70 \%$ of Alzheimer's disease and the remaining is the environmental factor. Most of the cases of Alzheimer's disease are late age onset; progresses post to an age of 60 [2]. At present, most established treatment strategy of Alzheimer's disease is inhibitors of cholinesterase, inactivate acetylcholinesterase enzyme (AChE) to augment the acetylcholine levels in brain. Inhibitors of acetylcholinesterase comprise drugs such as rivastigmine, tacrine, galantamine, donepezil, and memantine. Yet, there is no perfect drug for Alzheimer's disease treatment, besides only relieve the disease symptoms. [3] Herbal medicine gives a substitute option to alter symptoms and development of $\mathrm{AD}$.

\section{MATERIALS AND METHODS}

\section{Collection of plant materia}

The aerial parts of plant Polygonum glabrum employed for the current in quest was collected from Sri Venkateshwara University, Tirupati, India. The plant was authenticated by Dr. Madhava Chetty, Department of Botany. Specimen of voucher of the plant P. glabrum was conserved at SV institute herbarium library, Tirupati, A.P.
Preparation of ethanolic and methanolic extracts

The aerial parts of fresh and new medicinal plants collected. To get relieve of adhered dirt, aerial parts were rinsed and cleaned by means of distilled water, subsequently blotted thoroughly and dehydrated by means of shade in its consign of sunlight. The shadily dried aerial parts were crushed by means of a commercially available mixer. The obtained medicinal plant powder was an auxiliary filter to get fine powder and engaged for extraction by means of solvents. Almost 100 $\mathrm{g}$ of the crushed plant medicinal aerial parts was kept for Soxhlet extraction by means of $1000 \mathrm{ml}$ solvents, ethanol, and methanol. This accurate cycle was repetitive again and again, for hours to hardly many days, till the color of the solvent washing out away in the siphon of the Soxhlet. The extract was resolute under condensed pressure (P) and stock up in the refrigerator proceeding to commencing for advanced utilizations [4].

Phytochemical component observed in ethanolic and methanolic extract of $P$. glabrum

In-vivo study

The behavioral screening was done by the following methods [5-8].

Morris water maze test

Morris water maze test was performed for assessment of the retention of working (as a reference) and spatial memory in Wistar rats. The water maze contains of a circular tank $(150 \mathrm{~cm}$ in diameter and $40 \mathrm{~cm}$ in height). Water pool was alienated into 4 equally spaced quadrants all along the circumference of the pool. A flee platform $(10 \mathrm{~cm}$ in diameter) submerged $2 \mathrm{~cm}$ beneath the water surface was positioned in NW quadrant. Rats were trained to situate the hidden platform at a fixed spot in NW quadrant. All rats were kept to 1 session of 4 trials per day. During each trial, the animal was positioned in each quadrant to remove quadrant effects. All rats were left in the platform for 30 seconds and then removed and dried using a towel [9]. Rats failing to 


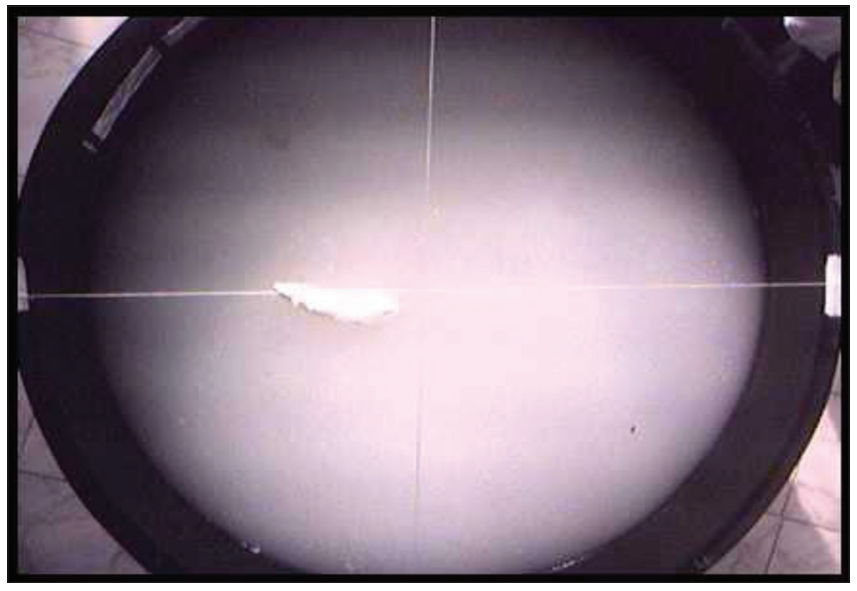

Fig. 1: Morris water maze test

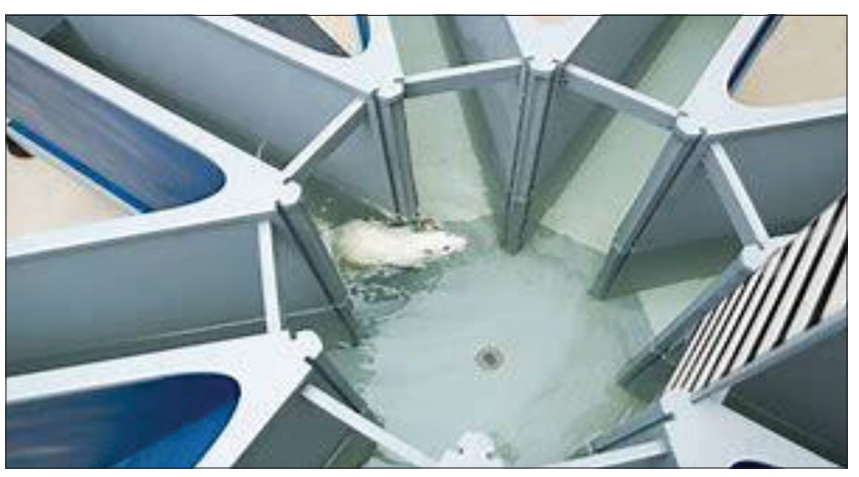

Fig. 2: Radial arm maze test

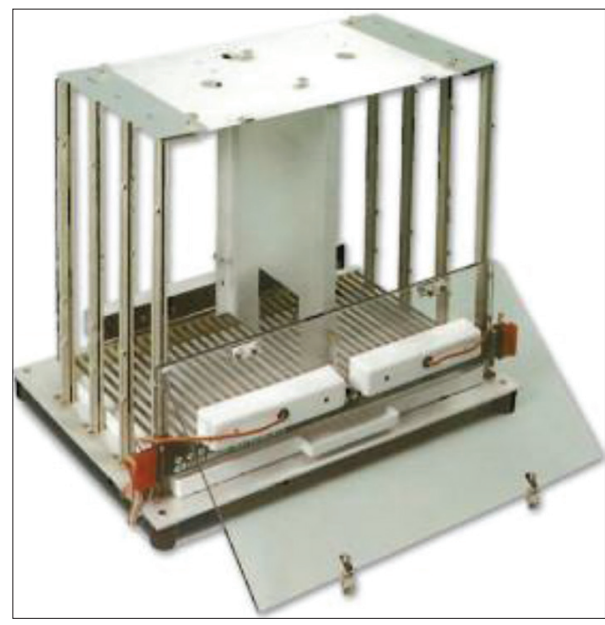

Fig. 3: Active avoidance test locate the platform within $60 \mathrm{~s}$ were directed to the platform. Twentyfour-hour after previous training, escape platform was taken away and probe trial was conducted. The cutoff time for animal to swim was set to at $60 \mathrm{~s}$ before the finish of the session. Time elapsed in escaping to the NW quadrant, that is, escape latency time was measured all through the trials of retention.

\section{Radial arm maze test}

Radial arm maze is a significant tool for the study of spatial memory in rats. It was employed as being described by Olton (1976) with minor modifications to assess spatial memory deficit in rats. The maze employed is $122 \mathrm{~cm}$ in diameter. It contains 8 chambers and each chamber is $46 \mathrm{~cm}$ in length from the center, $16.5 \mathrm{~cm}$ in wide, and its walls are $37.5 \mathrm{~cm}$ in height. The inner arena is $31 \mathrm{~cm}$ in diameter. Animals were kept overnight fasting prior to the test. At the start of the test, each animal was free in the center of the maze facing the baited arm and was permitted to explore the maze liberally in the $1^{\text {st }}$ day; not a single record was taken [10]. On a week basis, rats are released in the center of the maze facing the baited arm and set a maximum 6 min to locate the food. If 1 animal found the food before the finish of time, then the watch was stopped and elapsed time is registered. Numbers of entry to the right arm and the wrong arms were as well recorded for a week basis.

\section{Active avoidance (AA) test}

Measurements of AA responses were achieved by means of utilizing spaced trials behavioral procedural methods (20-trial sessions daily for every week). A conventional 2-way AA schedule was employed with trials starting at 30 sintervals time. Each trial begins with an accustomed signal (CS) (broadband noise of $68 \mathrm{~dB}$ lasting $7 \mathrm{~s}$ ), followed by an unconditioned stimulus (US) (foot shock of $1.5 \mathrm{~mA}, 3 \mathrm{~s}$ time duration) distributed through the floor grids. Passage responses through the conditioned stimulus (AA response) ended the conditioned stimulus and not permitted the beginning of unconditioned stimuli [11]. A reply after the onset of an escape response (unconditioned stimulus) ended both conditioned and unconditioned stimuli.

For each behavioral screening model, the animals were divided into 6 groups. Each group constitutes six animals. The study was approved by the Institutional Animal Ethical Committee (IAEC) with approval no. 03/IAEC/NCPA/M.Pharmacy 19-20.

All the three models carried out for ethanol and methanol extracts separately.

\section{Biochemical analysis}

The brain extract of both models was assayed for acetylcholine and acetylcholine esterase using standard protocol methods. Forebrain cortex and striatum were dissected by means of bilaterally from each frozen brain and crude mitochondrial portion was prepared from each region as previously illustrated methods. The determination of acetylcholine esterase activity was based on the degradation of acetyl thiocholine iodide by action of AchE into a subsequent product ultimately binds to5, 5-dithiobis-2-nitrobezoic acid,

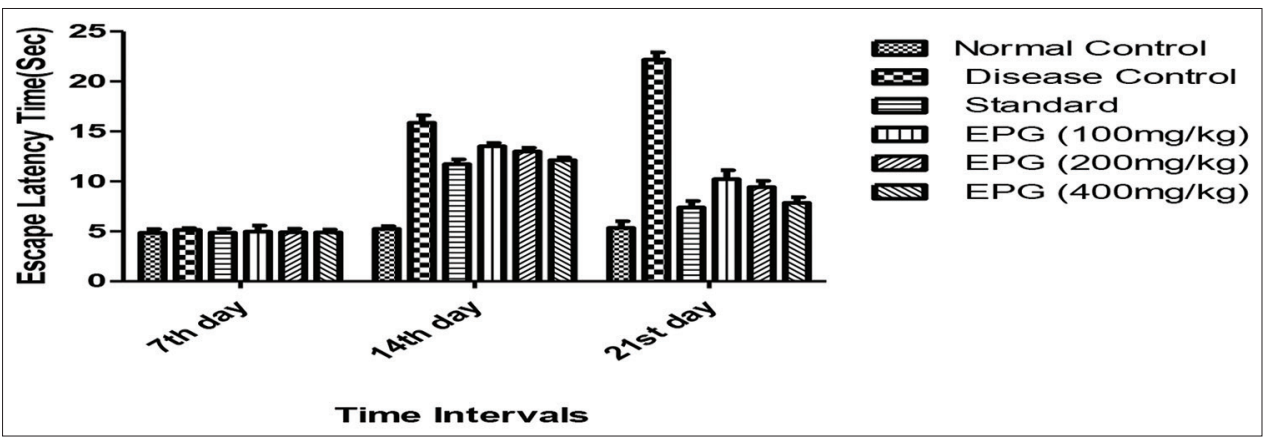

Fig. 4: Effect of ethanolic extract of Polygonum glabrum effectiveness on escape latency time made by means of Morris water maze test 
resulting in a yellow color [12]. Kinetics of the enzymatic reactions was followed over 3-5 min time at $412 \mathrm{~nm}$ wavelength. Values of AchE activity were deduced from the linear portion of the reaction curve and were expressed as units mmol acetyl thiocholine/min/g prot. The protein amount in the rat brain homogenates (forebrain cortex and striatum, ipsi- and contra-lateral regions) was measured by the Lowry method by means of bovine serum albumin as the reference standard.

\section{Statistical analysis of data}

Results were characterized as mean \pm S.E.M. The statistical variation amid the groups was computed in the characteristic of ANOVA with mean \pm S.E.M. The discrepancy was considered significant if $\mathrm{p}<0.05$.

\section{RESULTS}

Percentage yield of ethanolic and methanolic extract of Polygonum glabrum

The Acute toxicity valuation performed on animal sex posed that the Polygonum glabrum Methanolic and ethanolic extract was in safe and sound even at amount of 2 gram $/ \mathrm{kgb}$.w. The reasonably accurate and precise LD 50 is may possibly is $>2 \mathrm{gram} / \mathrm{kg}$ b.w. And hitherto supplementary not any lethality or any class of toxic retort and or moribund class of state was observed till the finish of the extent of investigational research.

Phytochemical component observed in ethanolic and methanolic extract of Polygonum glabrum

Data represented as mean \pm S.E.M values of 6 animals each. ${ }^{*} \mathrm{p}<0.05$, ${ }^{* *} \mathrm{p}<0.01$ (Dunnett t-test); control was compared with extract and standard treated groups were compared.

In relevant case of the of ethanolic and methanolic extract of Polygonum glabrum effectiveness on time lapse by means of radial arm maze test, the ethanolic and methanolic extract exposed considerably decline

Table 1: For ethanol, extract grouping is as follows

Group 1: Normal group (Tween 80)

Group 2: Disease control group-aluminum chloride (300 mg/kg, P.O.)

Group 3: Standard-rivastigmine $(0.3 \mathrm{mg} / \mathrm{kg}$, I.P. $)+$ aluminum

chloride $(300 \mathrm{mg} / \mathrm{kg}$, P.O.)

Group 4: Test-I-Polygonum glabrum $100 \mathrm{mg} / \mathrm{kg}+$ aluminum chloride (300 mg/kg, P.O.)

Group 5: Test II-Polygonum glabrum $200 \mathrm{mg} / \mathrm{kg}+$ aluminum chloride (300 mg/kg, P.O.)

Group 6: Test III-Polygonum glabrum $400 \mathrm{mg} / \mathrm{kg}+$ aluminum

chloride $(300 \mathrm{mg} / \mathrm{kg}$, P.O.)

The study duration is 20 days

Table 2: For methanol, extract grouping is as follows

Group 1: Normal group (Tween 80)

Group 2: Disease control group-aluminum chloride $(300 \mathrm{mg} / \mathrm{kg}$, P.O.)

Group 3: Standard-rivastigmine $(0.3 \mathrm{mg} / \mathrm{kg}$, I.P.) + aluminum

chloride $(300 \mathrm{mg} / \mathrm{kg}$, P.O.)

Group 4: Test-I-Polygonum glabrum $100 \mathrm{mg} / \mathrm{kg}$ + aluminum chloride (300 mg/kg, P.O.)

Group 5: Test II-Polygonum glabrum $200 \mathrm{mg} / \mathrm{kg}+$ aluminum chloride (300 mg $/ \mathrm{kg}$, P.O.)

Group 6: Test III-Polygonum glabrum $400 \mathrm{mg} / \mathrm{kg}+$ aluminum

chloride (300 mg/kg, P.O.)

The study duration is 20 days

Table 3: Percentage yields of extracts

\begin{tabular}{lll}
\hline S. No & Solvent & Percentage yield \\
\hline 1. & Ethanol & 12.4 \\
2. & Methanol & 10.5 \\
\hline
\end{tabular}

in time lapse. Ethanolic extract is more effective as comparison with methanolic extract.

\section{DISCUSSION}

Results obtained from water maze test demonstrated a dependable lessen in the time required to find the platform. The aluminum-treated rats showed high fluctuation in the time required to reach the platform from 1 day to another (Tables 1-4). The declining rate of the time needed to reach the platform was relatively steady for the control, standard, and group treated with extracts. These outcomes guide us to

Table 4: Particulars of qualitative phytochemical assessment

\begin{tabular}{|c|c|c|c|}
\hline S. No. & Test & $\begin{array}{l}\text { Methanolic } \\
\text { extract }\end{array}$ & $\begin{array}{l}\text { Ethanolic } \\
\text { extract }\end{array}$ \\
\hline \multirow[t]{5}{*}{1} & Alkaloids & & \\
\hline & Mayer's test & + & + \\
\hline & Dragondraff's test & + & + \\
\hline & Hager's test & + & + \\
\hline & Wagner's test & + & + \\
\hline \multirow[t]{2}{*}{2} & Carbohydrates & & \\
\hline & Mohlish's test & + & + \\
\hline \multirow[t]{3}{*}{3} & Reducing sugars & & \\
\hline & Fehling's test & + & + \\
\hline & Benedicts test & + & + \\
\hline \multirow[t]{3}{*}{4} & Saponins & & \\
\hline & Foam test & - & - \\
\hline & Forth test & - & - \\
\hline \multirow[t]{3}{*}{5} & Phytosterols & & \\
\hline & Salkowski test & + & + \\
\hline & Liebermann-Burchard's test & + & + \\
\hline \multirow[t]{3}{*}{6} & Phenolics & & \\
\hline & Ferric chloride test & - & - \\
\hline & Lead acetate test & - & - \\
\hline \multirow[t]{2}{*}{7} & Tannins & & \\
\hline & Ferric chloride test & + & + \\
\hline \multirow[t]{3}{*}{8} & Flavones and flavonoids & & \\
\hline & Lead acetate test & + & + \\
\hline & Alkaline reagent test & - & + \\
\hline \multirow[t]{2}{*}{9} & Glycosides & & \\
\hline & Keller-Killiani test & + & + \\
\hline \multirow[t]{3}{*}{10} & Proteins and amino acids & & \\
\hline & Ninhydrin test & + & + \\
\hline & Biuret test & + & + \\
\hline \multirow[t]{2}{*}{11} & Terpenoids & & \\
\hline & Salkowski's test & - & - \\
\hline \multirow[t]{3}{*}{12} & Fixed oils and fats & & \\
\hline & Spot test & - & - \\
\hline & Saponification test & - & - \\
\hline \multirow[t]{2}{*}{13} & Gum and mucilages & & \\
\hline & Ruthenium red solution & + & + \\
\hline
\end{tabular}

+: Positive, -: Negative

Table 5: Effect of ethanolic extract of Polygonum glabrum effectiveness made by means of active avoidance test

\begin{tabular}{|c|c|c|c|}
\hline \multirow[t]{2}{*}{ Groups } & \multicolumn{3}{|c|}{ Active avoidance } \\
\hline & $7^{\text {th }}$ day & $14^{\text {th }}$ day & $21^{\text {st }}$ day \\
\hline Normal & $25 \pm 0.31$ & $30 \pm 0.43$ & $32 \pm 0.59$ \\
\hline $\begin{array}{l}\text { Disease control } \\
\left(\mathrm{AlCl}_{3} 300 \mathrm{mg} / \mathrm{kg}\right)\end{array}$ & $16 \pm 0.27$ & $12 \pm 0.36$ & $7 \pm 0.39$ \\
\hline $\begin{array}{l}\text { Standard } \\
\text { (Rivastigmine } 0.3 \mathrm{mg} / \mathrm{kg} \text { I.P.) }\end{array}$ & $23 \pm 0.44$ & $26 \pm 0.61$ & $30 \pm 0.72^{* * *}$ \\
\hline EPG (100 mg/kg) & $18 \pm 0.48$ & $20 \pm 0.65$ & $23 \pm 0.51$ \\
\hline EPG (200 mg/kg) & $20 \pm 0.33$ & $22 \pm 0.49$ & $26 \pm 0.46$ \\
\hline EPG (400 mg/kg) & $22 \pm 0.57$ & $24 \pm 0.59$ & $28 \pm 0.63$ \\
\hline
\end{tabular}

Data represented as mean \pm S.E.M values of 6 animals each. ${ }^{*} \mathrm{p}<0.05,{ }^{* *} \mathrm{p}<0.01$ (Dunnett's t-test); control was compared with extract and standard treated groups were compared 


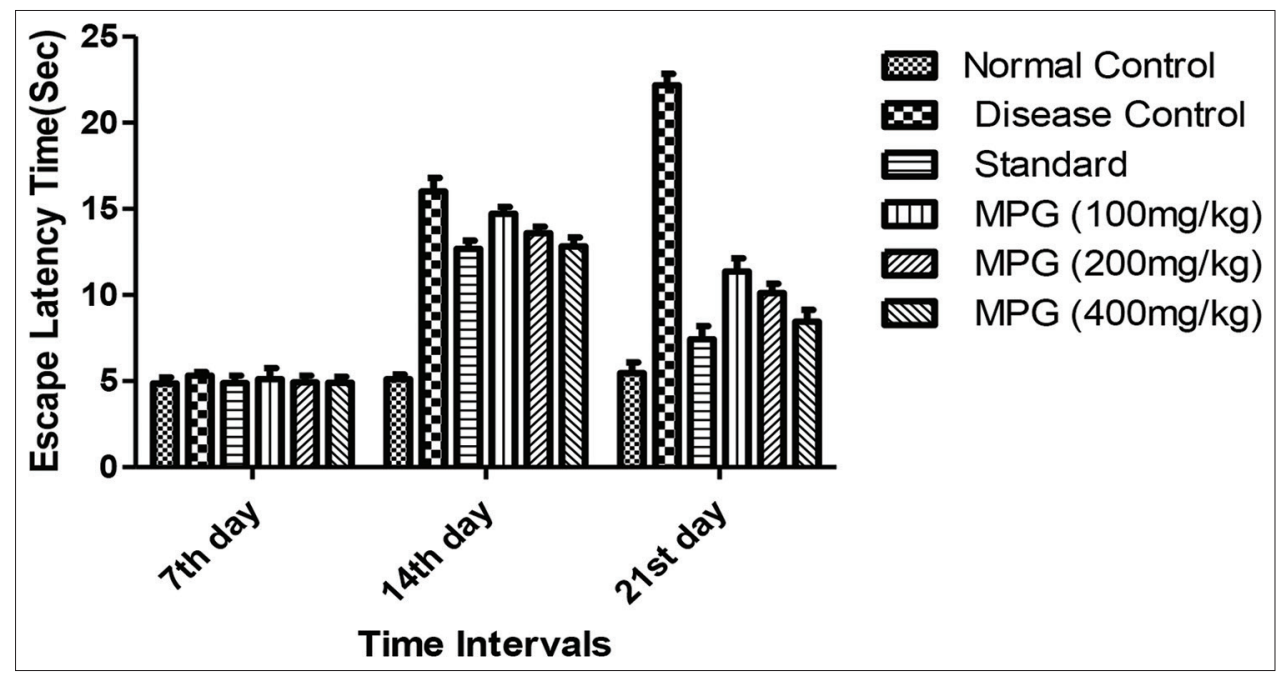

Fig. 5: Effect of methanolic extract of Polygonum glabrum effectiveness on escape latency time made by means of Morris water maze test

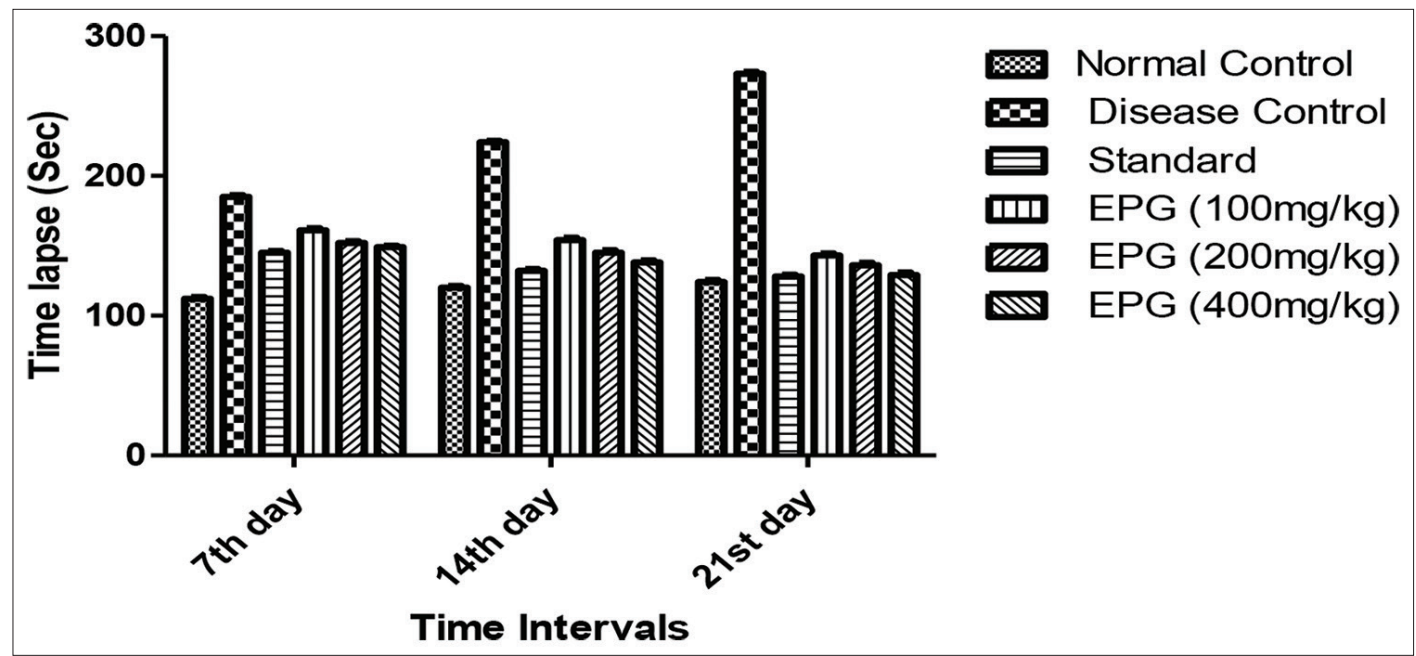

Fig. 6: Effect of ethanolic extract of Polygonum glabrum effectiveness on time-lapse made by means of radial arm maze test

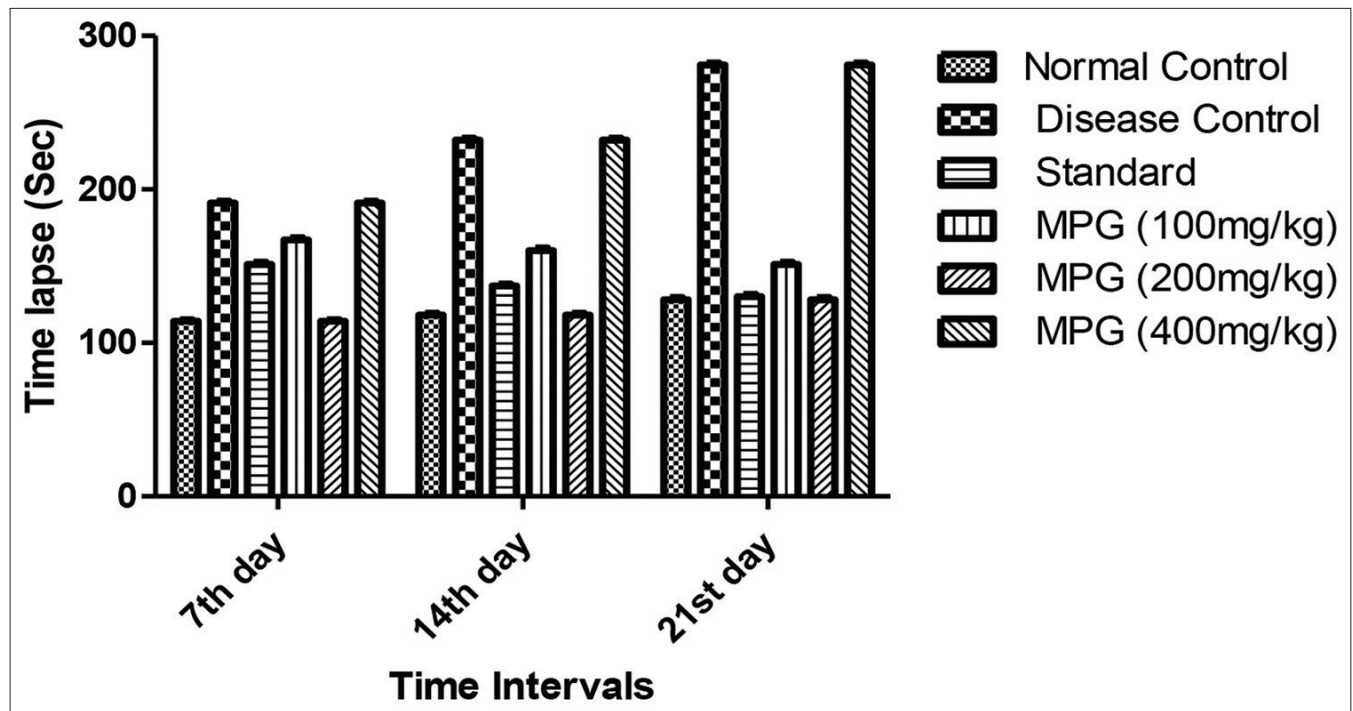

Fig. 7: Effect of methanolic extract of Polygonum glabrum effectiveness on time-lapse made by means of radial arm maze test 


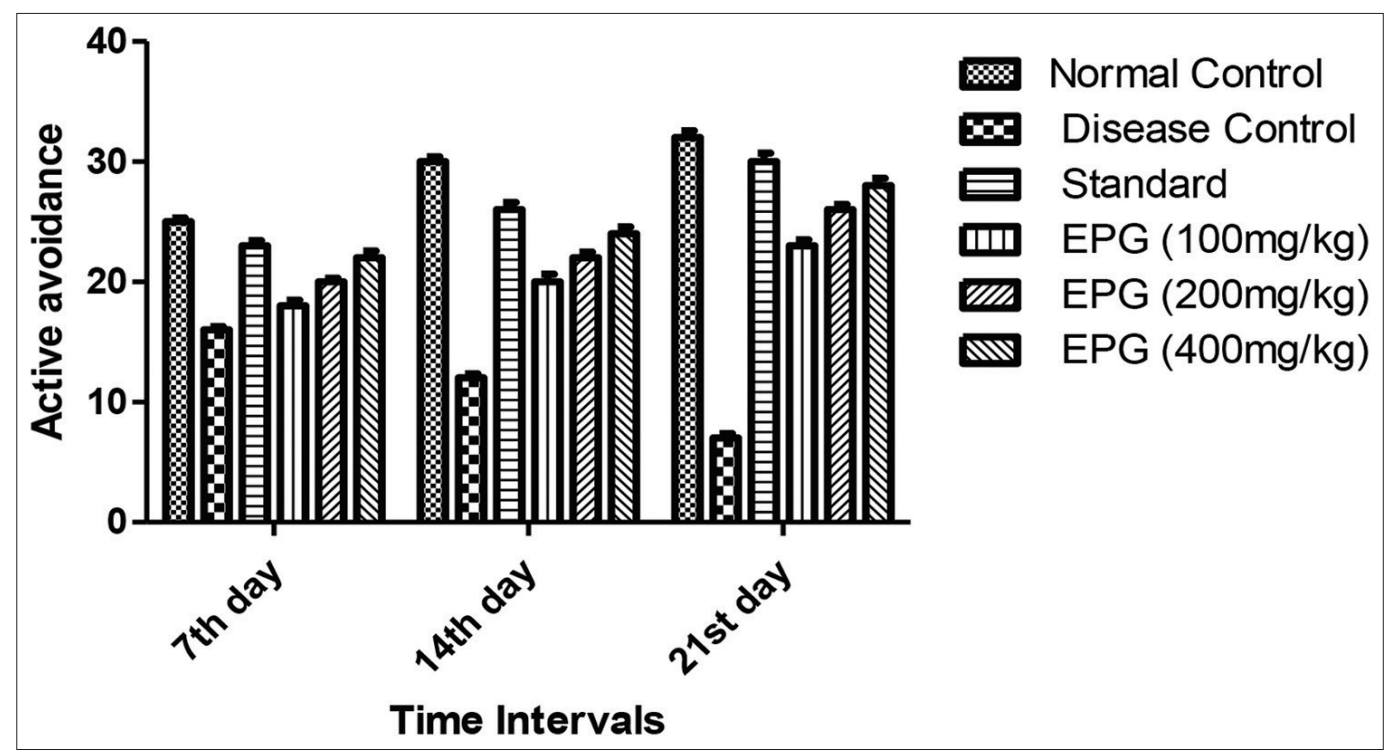

Fig. 8: Effect of ethanolic extract of Polygonum glabrum effectiveness made by means of active avoidance test

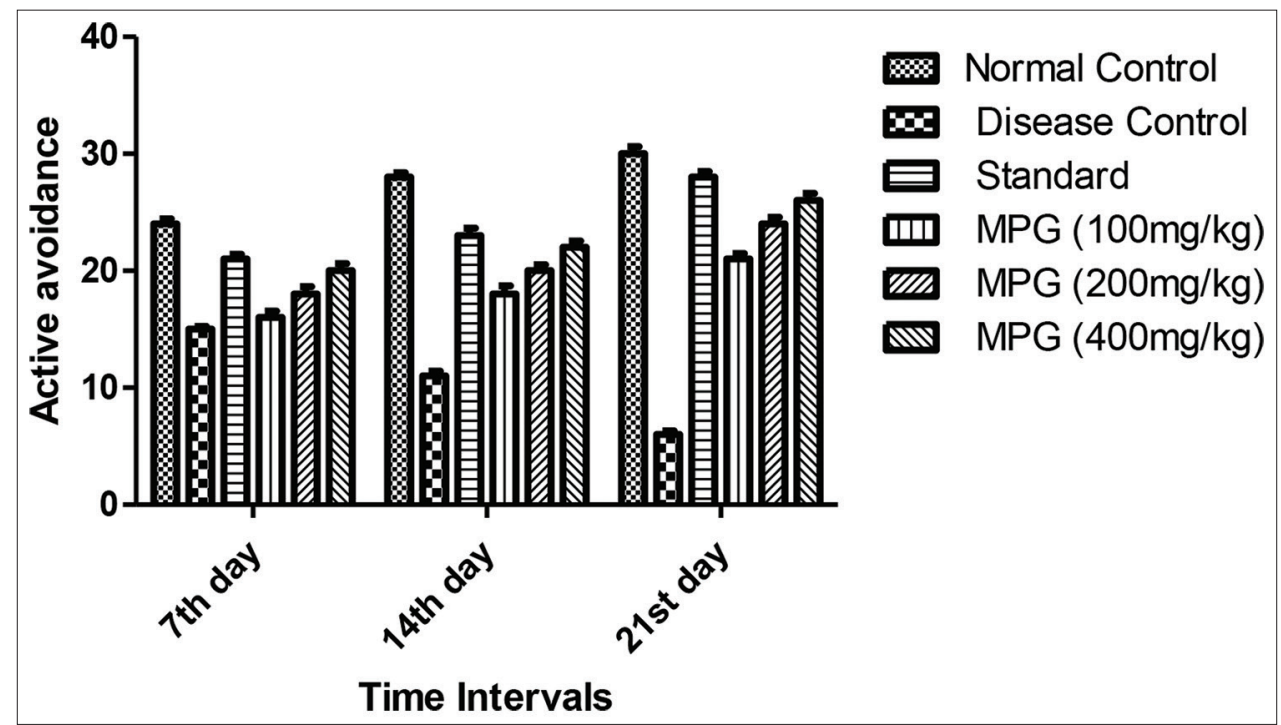

Fig. 9: Effect of methanolic extract of Polygonum glabrum effectiveness made by means of active avoidance test

Table 6: Effect of ethanolic extract of Polygonum glabrum effectiveness on escape latency time made by means of Morris water maze test

\begin{tabular}{llll}
\hline \multirow{2}{*}{ Groups } & \multicolumn{3}{l}{ Escape latency time (s) } \\
\cline { 2 - 4 } & $\mathbf{7}^{\text {th }}$ day & $\mathbf{1 4}^{\text {th }}$ day & $\mathbf{2 1}^{\text {st }}$ day \\
\hline $\begin{array}{l}\text { Normal } \\
\text { Disease control } \\
\text { (AlCl } 300 \mathrm{mg} / \mathrm{kg})\end{array}$ & $5.85 \pm 0.37$ & $5.23 \pm 0.29$ & $5.34 \pm 0.68$ \\
Standard & & $15.86 \pm 0.76^{\mathrm{a}}$ & $22.18 \pm 0.72^{\mathrm{a}}$ \\
(Rivastigmine & $4.87 \pm 0.39$ & $11.72 \pm 0.48$ & $7.39 \pm 0.64^{* * *}$ \\
$0.3 \mathrm{mg} / \mathrm{kg} \mathrm{I.P.)}$ & & & \\
EPG (100 mg/kg) & $4.97 \pm 0.60$ & $13.54 \pm 0.32$ & $10.22 \pm 0.89^{* * *}$ \\
EPG (200 mg/kg) & $4.91 \pm 0.34$ & $12.98 \pm 0.38$ & $9.43 \pm 0.63^{* * *}$ \\
EPG (400 mg/kg) & $4.89 \pm 0.29$ & $12.12 \pm 0.27$ & $7.84 \pm 0.57^{* * *}$ \\
\hline
\end{tabular}

guesstimate that extract may exert its effect by means of managing the lessening rate of time. The fluctuation in the time required to find the platform showed by means of AlCl3-treated rats was lessened by means of the ingestion of PG (Table 5). Suggesting that, although the effect of
Table 7: Effect of methanolic extract of Polygonum glabrum effectiveness made by means of active avoidance test

\begin{tabular}{|c|c|c|c|}
\hline \multirow[t]{2}{*}{ Groups } & \multicolumn{3}{|c|}{ Active avoidance } \\
\hline & $7^{\text {th }}$ day & $14^{\text {th }}$ day & $21^{\text {st }}$ day \\
\hline Normal & $24 \pm 0.46$ & $28 \pm 0.39$ & $30 \pm 0.61$ \\
\hline $\begin{array}{l}\text { Disease control } \\
\left(\mathrm{AlCl}_{3} 300 \mathrm{mg} / \mathrm{kg}\right)\end{array}$ & $15 \pm 0.24$ & $11 \pm 0.41$ & $6 \pm 0.32$ \\
\hline $\begin{array}{l}\text { Standard } \\
\text { (Rivastigmine } 0.3 \mathrm{mg} / \mathrm{kg} \text { I.P.) }\end{array}$ & $21 \pm 0.42$ & $23 \pm 0.66$ & $28 \pm 0.48^{* * *}$ \\
\hline MPG $(100 \mathrm{mg} / \mathrm{kg})$ & $16 \pm 0.56$ & $18 \pm 0.72$ & $21 \pm 0.49$ \\
\hline MPG (200 mg/kg) & $18 \pm 0.66$ & $20 \pm 0.51$ & $24 \pm 0.57$ \\
\hline MPG $(400 \mathrm{mg} / \mathrm{kg})$ & $20 \pm 0.63$ & $22 \pm 0.54$ & $26 \pm 0.61$ \\
\hline
\end{tabular}

PG was not revealed by means of monitoring the time needed to find the platform, yet, it was demonstrated that PG effect was resulted to the waning rate in the time and reverting the fluctuation produced by means of AlCl3 (Table 6). A high correlation was found between the 
radial maze test and the avoidance response in PG-treated groups. The correlations specify that both radial arm maze and AA test possibly will assess memory dispensation in a definite region of rat's brain. A part of

Table 8: Effect of methanolic extract of Polygonum glabrum effectiveness on escape latency time made by means of Morris water maze test

\begin{tabular}{llll}
\hline Groups & \multicolumn{3}{l}{ Escape latency time (s) } \\
\cline { 2 - 4 } & $\mathbf{7}^{\text {th }}$ day & $\mathbf{1 4}^{\text {th }}$ day & $\mathbf{2 1}^{\text {st }}$ day \\
\hline Normal & $4.87 \pm 0.34$ & $5.12 \pm 0.27$ & $5.47 \pm 0.63$ \\
Disease control & $5.32 \pm 0.21^{\text {a }}$ & $16.01 \pm 0.79^{\mathrm{a}}$ & $22.18 \pm 0.66^{\mathrm{a}}$ \\
(AlCl 300 mg/kg) & & & \\
Standard & $4.89 \pm 0.43$ & $12.67 \pm 0.48$ & $7.43 \pm 0.61^{* * *}$ \\
(Rivastigmine & & & \\
$0.3 \mathrm{mg} / \mathrm{kg} \mathrm{I.P.)}$ & & & \\
MPG (100mg/kg) & $5.12 \pm 0.65$ & $14.72 \pm 0.39$ & $11.37 \pm 0.77^{* * *}$ \\
MPG (200 mg/kg) & $4.93 \pm 0.39$ & $13.59 \pm 0.37$ & $10.12 \pm 0.54^{* * *}$ \\
MPG (400 mg/kg) & $4.91 \pm 0.34$ & $12.82 \pm 0.52$ & $8.45 \pm 0.68^{* * *}$ \\
\hline
\end{tabular}

Data represented as mean \pm S.E.M values of 6 animals each. ${ }^{*} \mathrm{p}<0.05,{ }^{* *} \mathrm{p}<0.01$ (Dunnett's t-test); control was compared with extract and standard treated groups were compared model of AA, demonstrated 2-fold lessening correct reactions from the $7^{\text {th }}$ to the $21^{\text {st }}$ day of assessment in $\mathrm{AlCl} 3$-treated animals as compared with the group of control (Tables 4, 7 and 8).

Aluminum provokes stable and reproducible depression of AA response, meaning $\mathrm{Al}$ damages rat cognitive functioning (Table 1). These consequences, all along with the obtained decreased AchE activity, suggest that $\mathrm{Al}$ exerts its toxic effects by altering transmission of cholinergic eventually imitated in neurobehavioral deficits [15] as shown in Tables 5,6,9-12. Aluminum is not only a selective cholinergic neurotoxin and possibly will also affect non-cholinergic neurons concerned in spatial learning. Earlier studies have exposed that attention and spatial learning were disturb in the Al-treated rats $[16,17]$. The AD rats as well shown a significant lessen in Ach levels along with an elevation in AchE activity (Table 7). Rivastigmine was used as a standardized drug as it is the only proven pharmacological therapy for the symptomatic treatment of $\mathrm{AD}$ [18]. Treatment of $\mathrm{AD}$ rats with rivastigmine as a protective or therapeutic agent led to an improvement in the oxidative stress status, as represented by a significant increase in the levels of activity in the activity cages and brain Ach levels as well as a significant decrease in the results of the radial arm maze and brain AchE levels when compared with the AD-induced groups of rats $[19,20]$.

Table 9: Effect of ethanolic extract of Polygonum glabrum effectiveness acetylcholine and acetylcholinesterase levels

\begin{tabular}{lll}
\hline Groups & Acetylcholine ( $\boldsymbol{\mu m o l} / \mathbf{m g}$ protein) & Acetylcholinesterase enzyme (unit/mg protein) \\
\hline Normal & $5.65 \pm 0.15$ & $0.54 \pm 0.04$ \\
Disease control ( $\left.\mathrm{AlCl}_{3} 300 \mathrm{mg} / \mathrm{kg}\right)$ & $0.87 \pm 0.05$ & $0.82 \pm 0.02$ \\
Standard (rivastigmine $0.3 \mathrm{mg} / \mathrm{kg} \mathrm{I.P.)}$ & $5.4 \pm 0.17$ & $0.56 \pm 0.03$ \\
EPG $(100 \mathrm{mg} / \mathrm{kg})$ & $2.7 \pm 0.23$ & $0.75 \pm 0.05$ \\
EPG $(200 \mathrm{mg} / \mathrm{kg})$ & $3.4 \pm 0.21$ & $0.63 \pm 0.04$ \\
EPG $(400 \mathrm{mg} / \mathrm{kg})$ & $4.9 \pm 0.29$ & $0.59 \pm 0.06$ \\
\hline
\end{tabular}

Data represented as mean \pm S.E.M values of 6 animals each. ${ }^{*} \mathrm{p}<0.05,{ }^{* *} \mathrm{p}<0.01$ (Dunnett's t-test); control was compared with extract and standard treated groups were compared

Table 10: Effect of methanolic extract of Polygonum glabrum effectiveness acetylcholine and acetylcholine esterase levels

\begin{tabular}{lll}
\hline Groups & Acetylcholine ( $\boldsymbol{\mu m o l} / \mathbf{m g}$ protein) & Acetylcholinesterase enzyme (unit/mg protein) \\
\hline Normal & $5.59 \pm 0.12$ & $0.57 \pm 0.05$ \\
Disease control $\left(\mathrm{AlCl}_{3} 300 \mathrm{mg} / \mathrm{kg}\right)$ & $0.85 \pm 0.03$ & $0.85 \pm 0.03$ \\
Standard (rivastigmine $0.3 \mathrm{mg} / \mathrm{kg} \mathrm{I.P.)}$ & $5.37 \pm 0.17$ & $0.58 \pm 0.02$ \\
MPG (100 mg/kg) & $2.5 \pm 0.2$ & $0.77 \pm 0.06$ \\
MPG (200 mg/kg) & $3.2 \pm 0.18$ & $0.66 \pm 0.03$ \\
MPG (400 mg/kg) & $4.7 \pm 0.25$ & $0.61 \pm 0.05$ \\
\hline
\end{tabular}

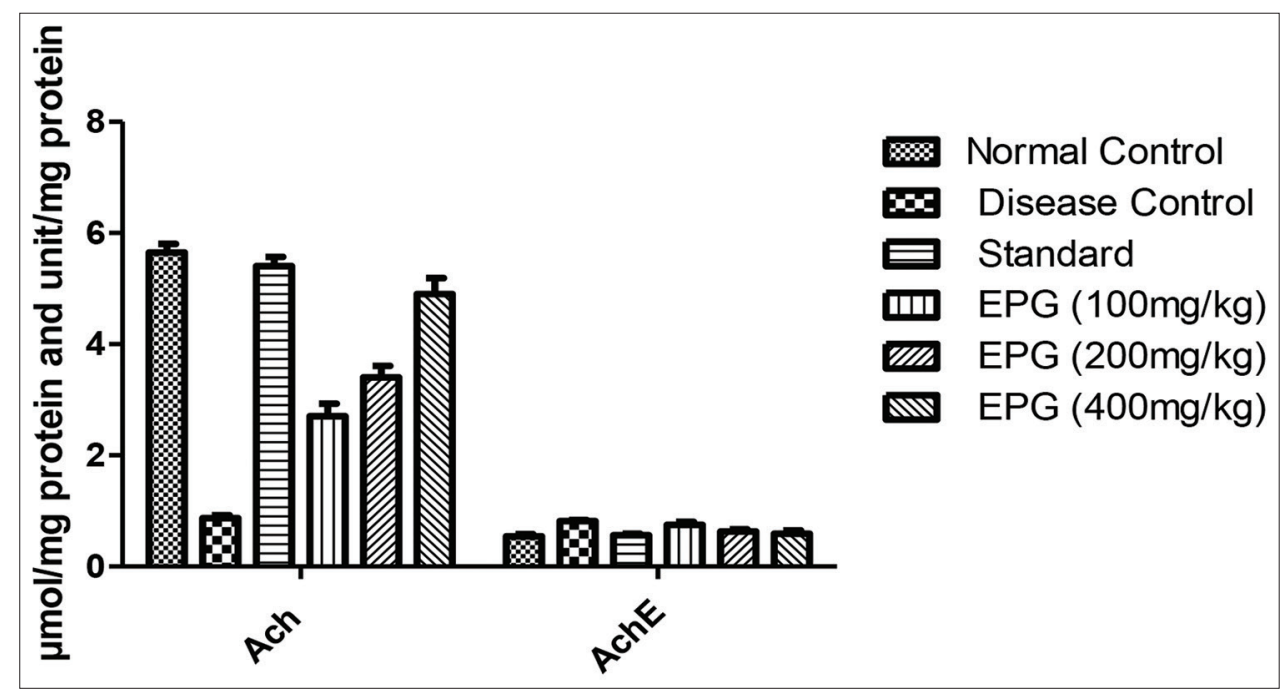

Fig. 10: Effect of ethanolic extract of Polygonum glabrum effectiveness acetylcholine and acetylcholine esterase levels 


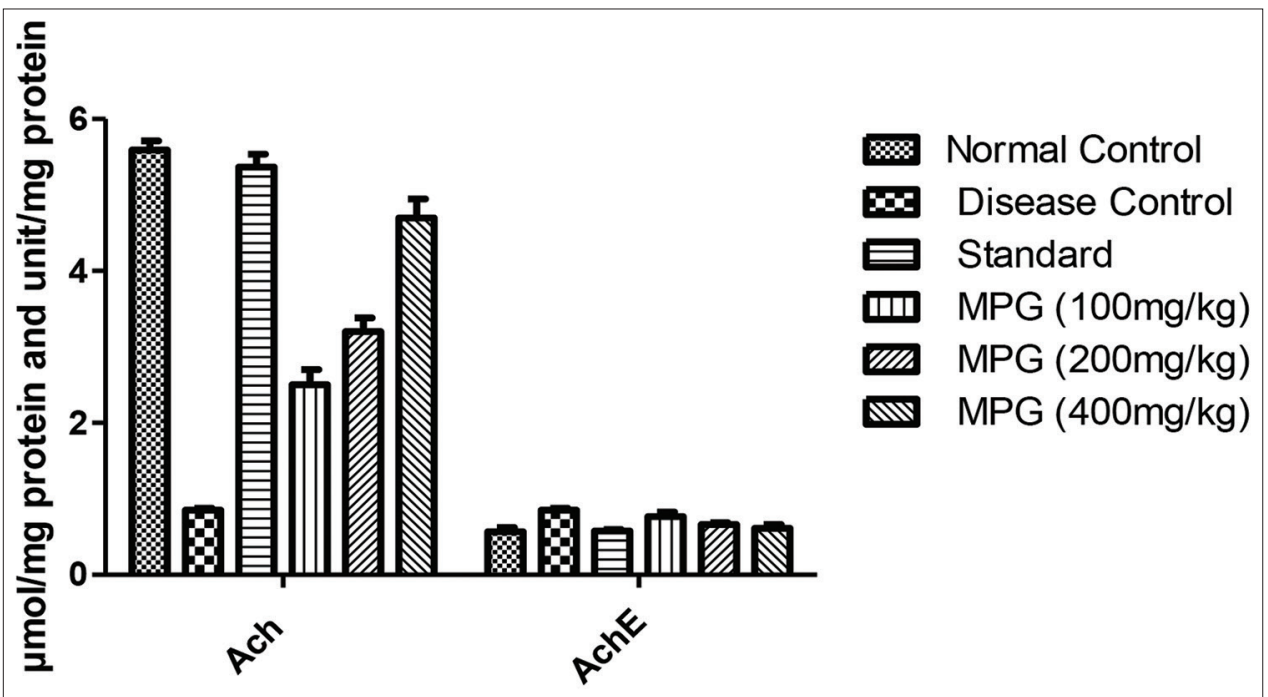

Fig. 11: Effect of methanolic extract of Polygonum glabrum effectiveness acetylcholine and acetylcholine esterase levels

Table 11: Effect of ethanolic extract of Polygonum glabrum effectiveness on time-lapse made by means of radial arm maze test

\begin{tabular}{llll}
\hline \multirow{2}{*}{ Groups } & \multicolumn{3}{l}{ Time-lapse (s) } \\
\cline { 2 - 4 } & $\mathbf{7}^{\text {th }}$ day & $\mathbf{1 4}^{\text {th }}$ day & $\mathbf{2 1}^{\text {st }}$ day \\
\hline Normal & $112 \pm 1.42$ & $120 \pm 1.36$ & $124 \pm 1.66$ \\
Disease control & $185 \pm 1.36$ & $224 \pm 1.21$ & $273 \pm 1.52$ \\
$\left(\mathrm{AlCl}_{3} 300 \mathrm{mg} / \mathrm{kg}\right)$ & & & \\
Standard (Rivastigmine & $145 \pm 1.47$ & $132 \pm 1.32$ & $128 \pm 1.41^{* * *}$ \\
$0.3 \mathrm{mg} / \mathrm{kg} \mathrm{I.P.)}$ & & & \\
EPG (100mg/kg) & $161 \pm 1.57$ & $154 \pm 1.83$ & $143 \pm 1.67^{* * *}$ \\
EPG (200 mg/kg) & $152 \pm 1.29$ & $145 \pm 1.75$ & $136 \pm 1.84^{* * *}$ \\
EPG (400 mg/kg) & $149 \pm 1.22$ & $138 \pm 1.59$ & $129 \pm 1.87^{* * *}$ \\
\hline
\end{tabular}

Data represented as mean \pm S.E.M values of 6 animals each. ${ }^{*} \mathrm{p}<0.05,{ }^{* *} \mathrm{p}<0.01$ (Dunnett's t-test); control was compared with extract and standard treated groups were compared

\section{CONCLUSION}

P. glabrum extract was instituted to be neuroprotective against $\mathrm{AlCl}_{3}-$ induced toxicity. Enhanced learning and memory were allied to the ingestion of extract in rats. Al overload, AChE hyperactivity is responsible for Alzheimer's disease which is neutralized or reduced with treatment of extract, which might be due to the synergistic action of its active constituents. Ethanolic extract was shown slightly higher efficacy as compared to methanolic extract. However, extensive research is needed to validate the anti-Alzheimer effect of extract active components against a variety of models of $\mathrm{AD}$ before entering into the clinical trials.

\section{AUTHORS' CONTRIBUTIONS}

Y. Suneesha - Article drafting. T. Vinay Kumar - Results and discussion.

\section{CONFLICTS OF INTEREST}

None.

\section{AUTHORS' FUNDING}

None.

\section{REFERENCES}

1. Kaur K, Kaur R, Kaur M. Recent advances in Alzheimer's disease: Causes and treatment. Int J Pharm Pharm Sci 2016;8:8-15.
Table 12: Effect of methanolic extract of Polygonum glabrum effectiveness on time-lapse made by means of radial arm maze test

\begin{tabular}{llll}
\hline \multirow{2}{*}{ Groups } & \multicolumn{2}{l}{ Time-lapse (s) } \\
\cline { 2 - 4 } & $\mathbf{7}^{\text {th }}$ day & $\mathbf{1 4}^{\text {th }}$ day & $\mathbf{2 1}^{\text {st }}$ day \\
\hline Normal & $114 \pm 1.23$ & $118 \pm 1.42$ & $128 \pm 1.57$ \\
$\begin{array}{l}\text { Disease control } \\
\text { (AlCl } 300 \mathrm{mg} / \mathrm{kg})\end{array}$ & $191 \pm 1.45$ & $232 \pm 1.37$ & $281 \pm 1.49$ \\
Standard & $151 \pm 1.52$ & $137 \pm 1.41$ & $130 \pm 1.55^{* * *}$ \\
(Rivastigmine 0.3 mg/kg I.P.) & & & \\
MPG (100 mg/kg) & $167 \pm 1.63$ & $160 \pm 1.77$ & $151 \pm 1.59^{* * *}$ \\
MPG (200 mg/kg) & $114 \pm 1.23$ & $118 \pm 1.42$ & $128 \pm 1.57$ \\
MPG (400 mg/kg) & $191 \pm 1.45$ & $232 \pm 1.37$ & $281 \pm 1.49$ \\
\hline
\end{tabular}

Data represented as mean \pm S.E.M values of 6 animals each. ${ }^{*} \mathrm{p}<0.05,{ }^{* *} \mathrm{p}<0.01$ (Dunnett's t-test); control was compared with extract and standard treated groups were compared

2. Torgal SS, Sugato CH. Effect of metformin and simvastatin in diazepam-and sodium nitrite-induced anterograde amnesia in male Swiss albino mice. Int J Pharm Pharm Sci 2018;10:18-22.

3. Fisiopatología del la Enfermedad de Alzheimer: Nuevos Mecanismos; 2014. Available from: http://www.revneurol.com/sec/RSS/noticias. php?idNoticia $=4446$.

4. Nichols E, Szoeke CE, Vollset SE, Abbasi N, Abd-Allah F, Abdela J, et al. Global, regional, and national burden of Alzheimer's disease and other dementias, 1990-2016: A systematic analysis for the Global Burden of Disease Study 2016. Lancet Neurol 2019;18:88-106.

5. Burns A, Jacoby R, Levy R. Neurological signs in Alzheimer's disease. Age Ageing 1991;20:45-5.

6. Tripathi KD. Essentials of Medical Pharmacology. $6^{\text {th }}$ ed. New Delhi: Jaypee Brothers Medical Publishers Private Ltd.; 2009.

7. Reitz C. Alzheimer's disease and the amyloid cascade hypothesis: A critical review. Int J Alzheimers Dis 2012;2012:369808.

8. Mesulam MM. Cholinergic circuitry of the human nucleus basalis and its fate in Alzheimer's disease. J Comp Neurol 2013;521:4124-44.

9. Sassin I, Schultz C, Thal DR, Rüb U, Arai K, Braak E, et al. Evolution of Alzheimer's disease-related cytoskeletal changes in the basal nucleus of Meynert. Acta Neuropathol 2000;100:259-69.

10. Francis PT, Ramírez MJ, Lai MK. Neurochemical basis for symptomatic treatment of Alzheimer's disease. Neuropharmacology 2010;59:221-9.

11. Goto Y, Niidome T, Hongo H, Akaike A, Kihara T, Sugimoto H. Impaired muscarinic regulation of excitatory synaptic transmission in the APPswe/PS1dE9 mouse model of Alzheimer's disease. Eur J Pharmacol 2008;583:84-91.

12. Nordberg A, Winblad B. Reduced number of $[3 \mathrm{H}]$ nicotine and $[3 \mathrm{H}]$ acetylcholine binding sites in the frontal cortex of Alzheimer brains. Neurosci Lett 1986;72:115-20.

13. Flynn DD, Mash DC. Characterization of L-[3H]nicotine binding in 
human cerebral cortex: Comparison between Alzheimer's disease and the normal. J Neurochem 1986;47:1948-54

14. Jiang T, Tan L, Chen Q, Tan MS, Zhou JS, Zhu XC, et al. A rare coding variant in TREM2 increases risk for Alzheimer's disease in Han Chinese. Neurobiol Aging 2016;42:217.

15. Sassin I, Schultz C, Thal DR, Rüb U, Arai K, Braak E, et al. Evolution of Alzheimer's disease-related cytoskeletal changes in the basal nucleus of Meynert. Acta Neuropathol 2000;100:259-69.

16. Francis PT, Ramírez MJ, Lai MK. Neurochemical basis for symptomatic treatment of Alzheimer's disease. Neuropharmacology 2010;59:221-9.

17. Goto Y, Niidome T, Hongo H, Akaike A, Kihara T, Sugimoto H.
Impaired muscarinic regulation of excitatory synaptic transmission in the APPswe/PS1dE9 mouse model of Alzheimer's disease. Eur J Pharmacol 2008;583:84-91.

18. Kilgard MP, Merzenich MM. Cortical map reorganization enabled by nucleus basalis activity. Science 1998;279:1714-8.

19. Van Beek AH, Claassen JA. The cerebrovascular role of the cholinergic neural system in Alzheimer's disease. Behav Brain Res 2011;221:537-42.

20. Barbelivien A, MacKenzie ET, Dauphin F. Galanin inhibits the vasodilatatory basalocortical cholinergic system in the anaesthetized rat. Neuroreport 1995;6:1849-52 